\title{
Photogrammetric analysis of 1984-89 surface altitude change of the partially debris-covered Eliot Glacier, Mount Hood, Oregon, U.S.A.
}

\author{
S. C. LundSTROM* \\ Institute of Arctic and Alpine Research and Department of Geological Sciences, University of Colorado, \\ Boulder, CO 80309-0450, U.S.A. \\ A. E. McCafferty and J. A. Coe \\ U.S. Geological Survey, Box 25046-MS 964, Denver, CO 80225, U.S.A.
}

\begin{abstract}
Photogrammetric analysis of Eliot Glacier, Mount Hood, Oregon indicates an average thinning of the ablation area of $4.2 \mathrm{~m}$ during 1984-89. Thinning is generally more marked near the equilibrium line, where debris cover is absent, than on the lowest part of the glacier, where superglacial debris thickness is greater than $1.0 \mathrm{~m}$. The pattern of glacier thickness change is partly related to the reduction of ablation with increasing debris thickness, though flow kinematics must also be important to change in ice thickness.
\end{abstract}

\section{INTRODUGTION}

Superglacial debris commonly occurs on mountain glaciers in various climatic settings and can be significant in its effect on reducing ice ablation rate relative to clean ice ablation (Bozhinsky and others, 1986; Nakawo and Young, 1982). Changes in the volume of mountain glaciers may be a significant component of historic sealevel rise (Meier, 1984). Because significant portions of some mountain glacier inventories include debris-covered glaciers (Corte and Espizua, 1981), the effect of debris on glacier mass balance and volume change should be included in programs of glacier monitoring by remote sensing. Here we report on the use of analytical photogrammetry to study the pattern of surface altitude change with time and the relationship of this pattern to debris cover on Eliot Glacier, a temperate glacier in the northwestern United States $\left(45^{\circ} 23^{\prime} \mathrm{N}, 121^{\circ} 41^{\prime} \mathrm{W}\right)$.

Eliot Glacier is situated on the northeast flank of Mount Hood (Fig. 1), a large (altitude $3425 \mathrm{~m}$ ), dormant stratovolcano (Crandell, 1980) in the Cascade Range of northern Oregon. Steep, avalanche-prone slopes composed of incompetent volcaniclastic material supply debris to the glacier accumulation area (Fig. 2). After predominantly high-level englacial transport (Small, 1987), debris melts out of englacial position to cover more than half of the ablation area, the portion of the glacier to which this study is confined.

\footnotetext{
* Present address: U.S. Geological Survey, 101, Convention Center Drive, Las Vegas, Nevada 89109, U.S.A.
}

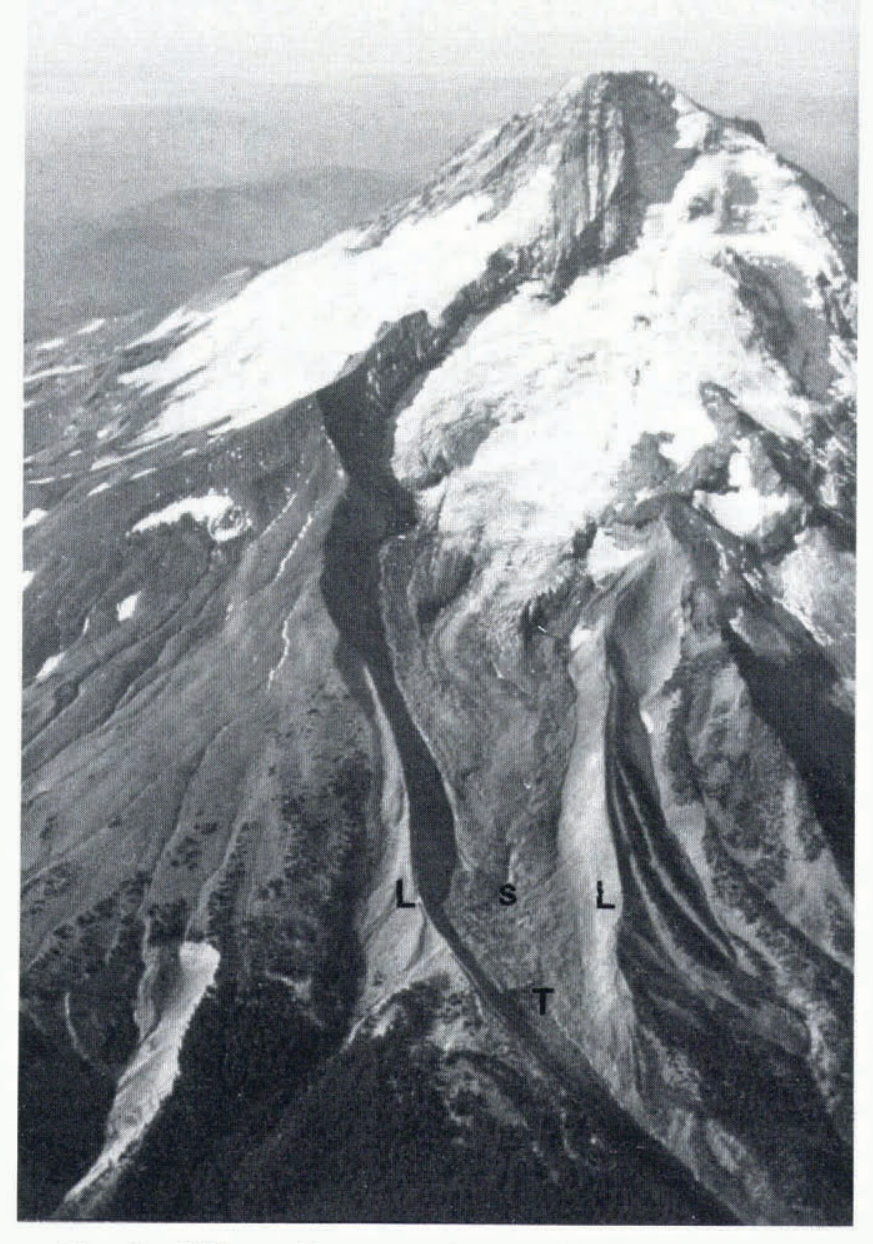

Fig. 1. Oblique view to southwest of Eliot Glacier on Mount Hood (October, 1987), indicating terminus of debris-covered glacier $(T)$, up-glacier limit of stagnant ice $(s)$ and adjoining lateral moraines $(L)$, with crests 40$90 \mathrm{~m}$ above modern glacier. Photograph by W.E. Scott. 


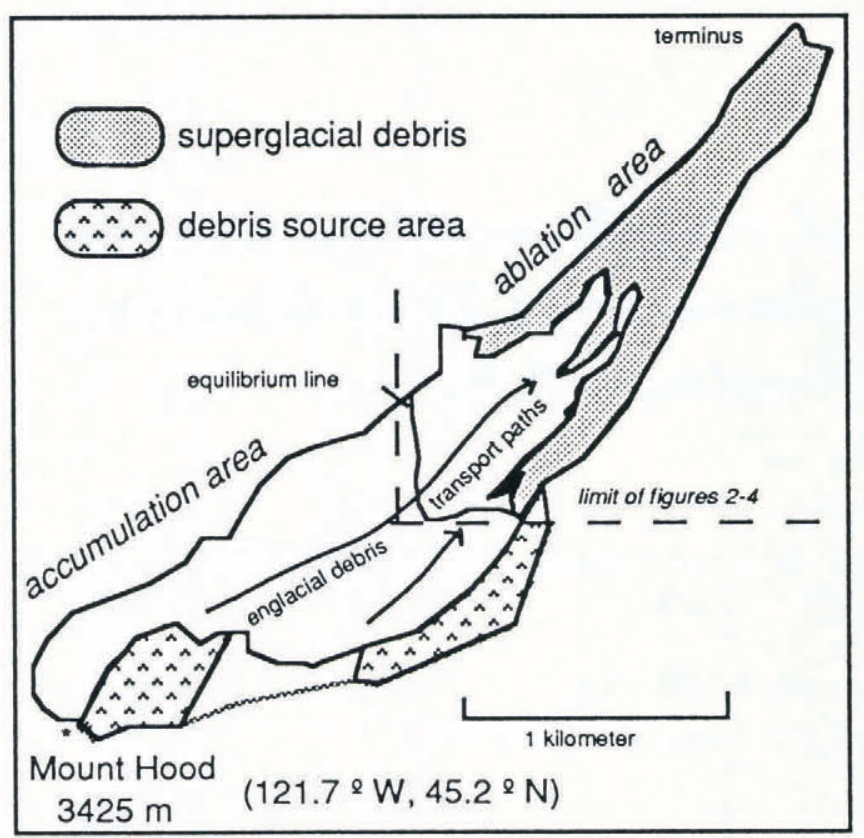

Fig. 2. Map of Eliot Glacier high-level debris transport system.

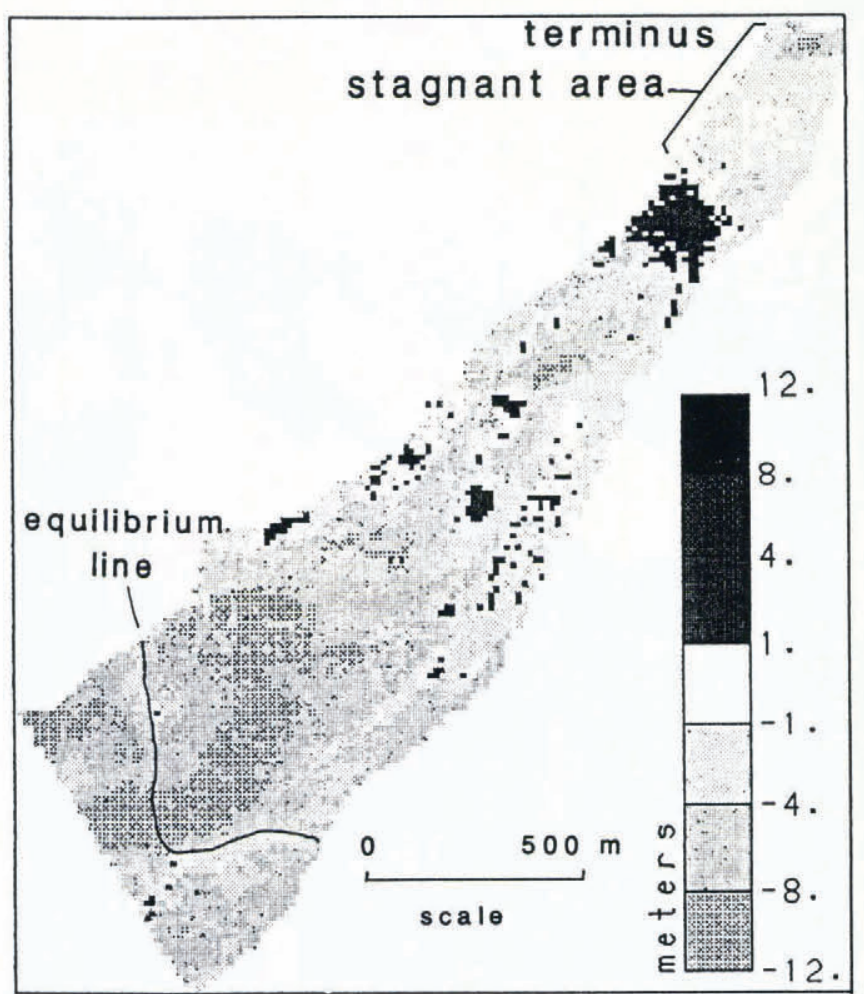

Fig. 3. Lower Eliot Glacier surface altitude change from 1984-89. Light-to-medium grey tones indicate thinning, dark grey indicates thickening, acording to scale.

\section{METHODS}

Photogrammetric measurements were made from color diapositive film transparencies of U.S. Department of Agriculture vertical air photographs $(1: 12000)$ taken in late summer, 1984 and 1989. Two stereoscopic models were required to cover the glacier ablation area for each year. Ground control for the models was obtained by

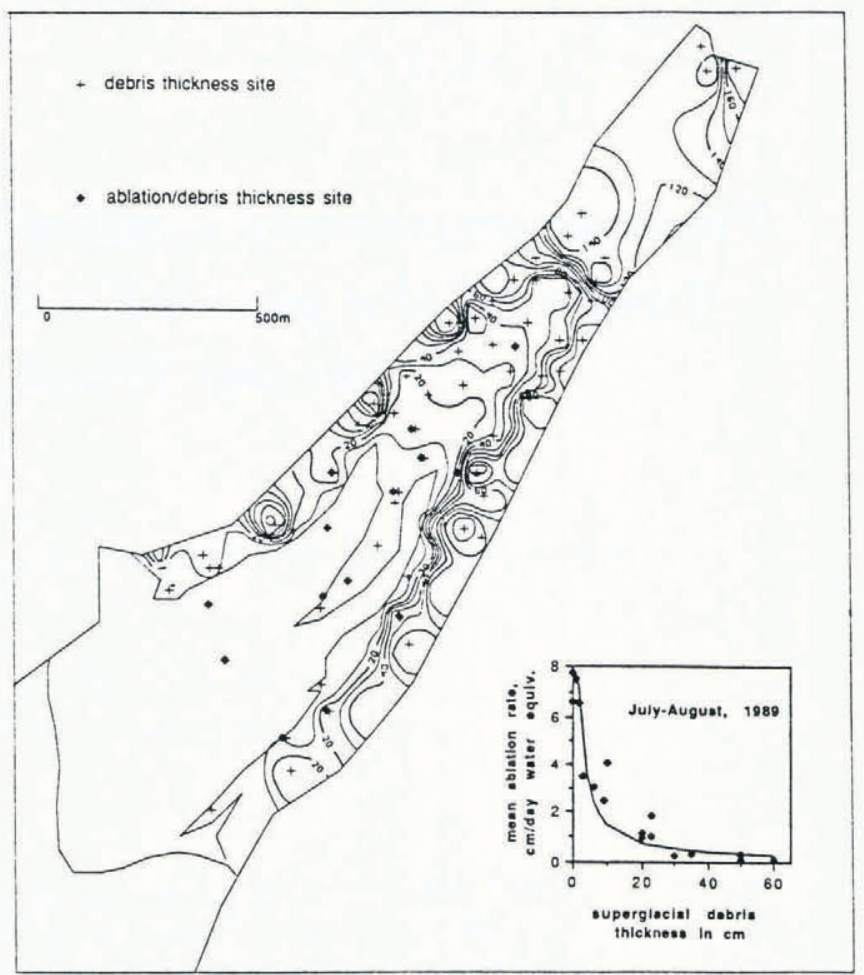

Fig. 4. Estimated superglacial debris thickness distribution, $10 \mathrm{~cm}$ contour interval. Crosses indicate sites where debris thickness only was directly measured; diamonds indicate sites where ice ablation rate was measured, as well as debris thickness. Contours drawn on $50 \mathrm{~m}$ gridded interpolation of sites of known thickness. Inset shows measured ice ablation rate and superglacial debris thickness, along with curve depicting an inverse relationship.

using a theodolite and an electronic distance measuring system to establish stable and photo-identifiable control stations peripheral to the glacier.

Digital elevation models (DEM) of the surface of lower Eliot Glacier, including the entire ablation area, were created by using an analytical stereoplotter and associated grid measurements software. For identical location grids over the glacier surface, altitudes were measured at approximately 10000 points for each year. Nodes on the grids were spaced at $10 \mathrm{~m}$ along northerly and easterly axes. The 1984 DEM was subtracted from the 1989 DEM to create an altitude difference map (Fig. $3)$. Estimated errors are $0.5 \mathrm{~m}$ on the altitude measurements, and less than $1.0 \mathrm{~m}$ on grid locations and altitude differences. The DEMs and the altitude difference map were analyzed and displayed using U.S. Geological Survey computer software (Cordell and others, 1992). We assume that subglacial erosion during 1984-89 is negligible relative to errors on altitude differences, and that altitude differences provide a measure of glacier thickness changes.

During 1987-89, superglacial debris thickness was determined by excavation at 32 sites on Eliot Glacier, and the ablation rate of underlying ice was monitored at 16 of these sites. Measurement locations were either directly surveyed or photo-identified in the field for later 


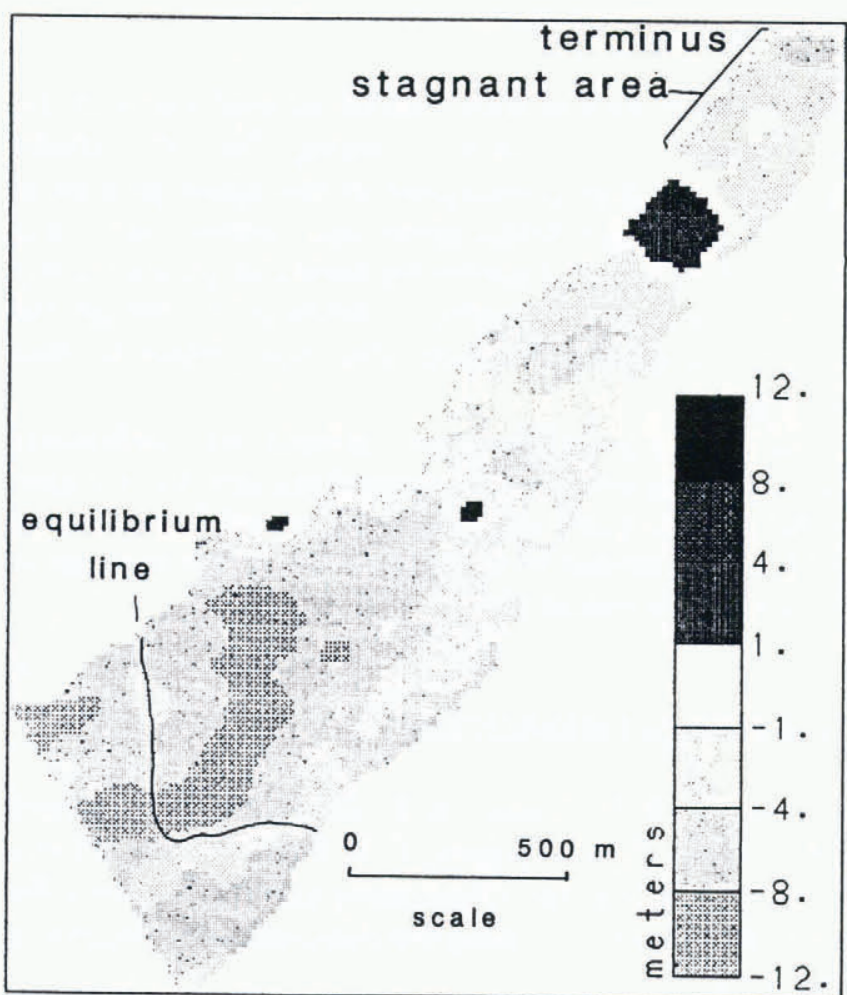

Fig. 5. Surface altitude change averaged over $25 \mathrm{~m}$ radius, using the same grey scale as Figure 3. Note similar pattern to Figure 3, but with removal of high spatial frequencies.

$$
\frac{\partial h}{\partial t}=b+\int_{z_{\mathrm{b}}}^{z_{\mathrm{a}}} \operatorname{div} \mathbf{v} \mathrm{d} z .
$$

Therefore, the observed inverse relationship between superglacial debris thickness and ablation rate for debris thickness greater than $1 \mathrm{~cm}$ (Fig. 4, inset) should affect the pattern of glacier thickness change where superglacial debris is present to affect ice mass balance.

Averaged glacier thickness change $\Delta h$ (Fig. 5) shows some positive correlation $\left(r^{2}=0.59\right)$ to measured superglacial debris thickness $S$ (Figs 4 and 6); less correlation $\left(r^{2}=0.45\right)$ of $\Delta h$ to the grid interpolation of $S$ probably reflects errors of the interpolation. However, scatter of $\Delta h$ about the regression line is particularly great where debris cover is absent and therefore where $S$ is most precisely measured (at zero).

Aside from errors of measurement and interpolation, variability of $\Delta h$ should also relate to flow pattern independent of ice mass balance, as in Equation (1). In the stagnant area, with a negligible glacier flow, the average rate of ice thickness changes, $-0.33 \mathrm{~m} \mathrm{a}^{-1}$, is a measure of the net ice balance rate under a debris cover estimated to be $1.0-1.8 \mathrm{~m}$ thick. Near the equilibrium line, the mean thinning rate of a relatively clean part of the glacier is an order of magnitude higher, but the greater thinning must be predominantly affected by flow divergence. The thinning of the glacier above the photogrammetric location. These data and the photogrammetrically mapped margin of superglacial debris are the basis for the interpolation and contouring of a grid of superglacial debris thickness (Fig. 4). The original elevation data on the $10 \mathrm{~m}$ grid were regridded to $50 \mathrm{~m}$ nodes to be compatible with grids developed from more sparsely distributed field data on debris thickness. Regridding was done using a bilinear averaging algorithm, followed by decimation.

\section{RESULTS}

The ablation zone of Eliot Glacier has thinned an average of $4.2 \mathrm{~m}$ during 1984-89, but glacier thickness change is not spatially uniform. Glacier thinning is generally greater near the equilibrium line than near the terminus (Fig. 3). A prominent area of thickening occurs immediately up-glacier of a terminal stagnant area. The area of thickening differs from the stagnant area in having measureable longitudinal velocity and slope, which the stagnant area lacks. Some of the thickness change patterns of high spatial frequency are artifacts of the displacement of local topographic highs and lows commonly associated with debris cover. This effect is reduced by averaging the altitude difference grid over a $25 \mathrm{~m}$ radius (Fig. 5).

The rate of glacier thickness change $\partial h / \partial t$ at any point is a sum of ice mass balance rate $b$ and horizontal flow divergence div $\mathbf{v}$ integrated over ice thickness $h=z_{\mathrm{s}}-z_{\mathrm{b}}$ where $z_{\mathrm{s}}$ and $z_{\mathrm{b}}$ are respective surface and basal elevations of the glacier at a given location:
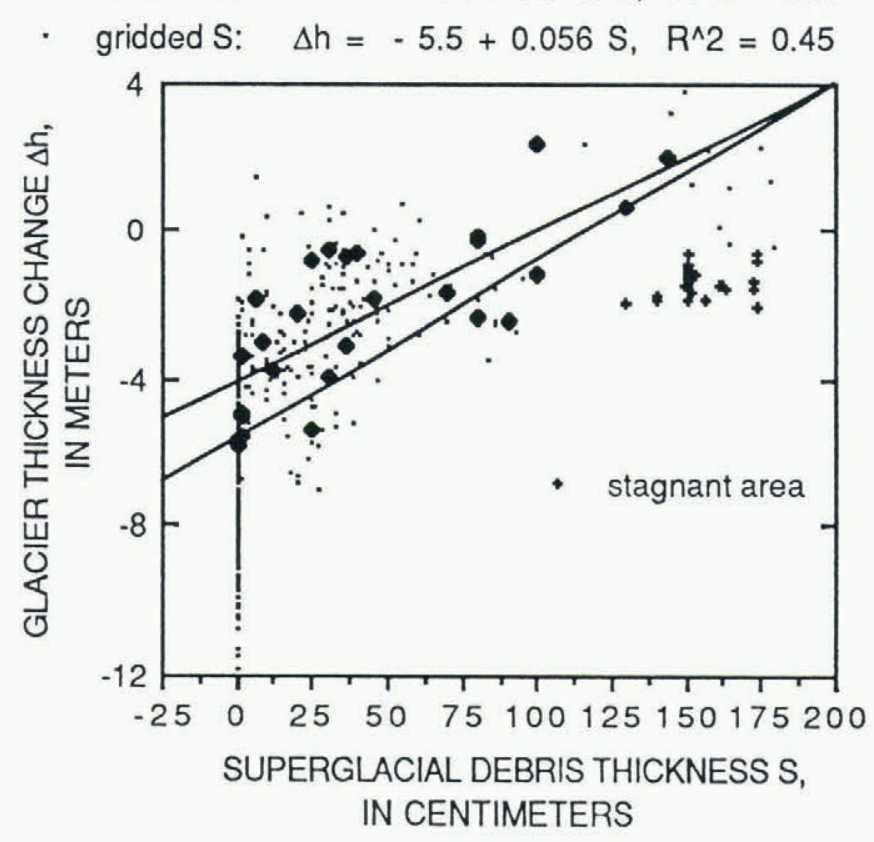

Fig. 6. Eliot Glacier thickness change $\Delta$ h from $1984-89$ plotted against superglacial debris thickness $S$. For each point, $\Delta h$ represents the averge of altitude change for nine locations within a $50 \mathrm{~m}$ grid cell. The bold diamonds indicate mesured debris thickness within the grid cell, whereas small dots and crosses (stagnant area) represent estimate debris thickness from a grid interpolation on the sites of measured thickness and the limit of debris cover. Regression lines, equations and correlations are shown for $\Delta h$ regressed on measured and interpolated $S$. 
equilibrium line can only relate to an effect of extensional flow greater than net accumulation; similar extensional thinning may be affecting the adjoining upper ablation area. Similarly, the area of increase in glacier thickness which adjoins the stagnant area is a result of the effect of strain from compressive flow exceeding net ablation beneath debris.

\section{DISCUSSION}

The pattern of glacier thickness change is likely to be partially related to the reduction of ice ablation with increasing debris thickness, though flow kinematics must also be important to the $\Delta h$ pattern. The rate of change of debris cover thickness $\partial S / \partial t$ is also affected by the kinematics of glacier flow:

$$
\frac{\partial S}{\partial t}=-\operatorname{div} \mathbf{v} S-\frac{b C_{\mathrm{d}}}{(1-P)}+D
$$

where the first term on the right side is vertical strain rate (equal to horizontal flow divergence $\operatorname{div} \mathbf{v}$, given no change in debris density) times debris thickness $S$; the second term refers to debris melt-out with net ice balance $b$, englacial volumetric concentration $C_{\mathrm{d}}$, and porosity $P$ of the superglacial debris; and $D$ is direct subaerial deposition. Therefore, compressive flow that contributes positively to glacier thickening also increases debris thickness and reduces net ice ablation. A reduction of ablation, in turn, would have a positive effect on ice thickness; for example, a reduction in ablation would thicken ice at a point that previously had mass balance in equilibrium with flow divergence.

The pattern of glacier thickness change resulting from the propagation of a kinematic wave into an area of debris-covered ice is thus likely to be affected by the debris cover. The observed 1984-89 pattern of $\Delta h$ on Eliot Glacier may be the result of a kinematic wave through debris-covered ice that is presently impinging on stagnant ice. The presently greater rate of thinning upglacier is a process that would eventually lead to stagnation of a new reach of glacier, and an analogous process probably lead to the stagnation of the lower reach of the glacier in the past. The reduction of glacier surface slope during thinning of a partially debris-covered glacier may be significant to glacier hydrology for the case of pressurized englacial hydraulic conduits (Shreve, 1972).

Despite the relatively protective effect of debris cover on ablation, lower Eliot Glacier is generally thinning significantly. The 1984-89 mean thinning rate represents an annual loss of about one per cent of the 1980 volume of Eliot Glacier (Driedger and Kennard, 1986). The modern rate of thinning is greater than three times the mean rate of thinning of the glacier below the crests of adjoining lateral moraines (Fig. 1), which were associated with an advance of Eliot Glacier around $1740 \mathrm{AD}$ (Lawrence, 1948). The accelerated thinning rate may be a response to recent local climatic amelioration, but the absence of long-term local climate data precludes assessment of this hypothesis.

\section{CONGLUSIONS}

The ablation area of Eliot Glacier thinned significantly, at a mean rate of $0.8 \mathrm{~m} \mathrm{a}^{-1}$ during 1984-89. Glacier thinning was least pronounced on the lowest portion of the glacier where debris cover was greater than $1.0 \mathrm{~m}$ thick. The pattern of glacier thickness change may partly relate to the protective effect of debris cover, though the change in glacier thickness also must relate to flow divergence.

Modern photogrammetric methods are particularly useful in the study of debris-covered glaciers. More studies of the inventory and changing geometry of debris-covered glaciers are needed to understand better the response of mountain glaciers to climate change.

\section{ACKNOWLEDGEMENTS}

We thank T.N. Caine, W.J. Gerstel, R. M. Iverson, M. F. Meier, J. A. Messerich, C. L. Pillmore, K. L. Pierce, the Cascades Volcano Observatory and the Mazamas for contributed expertise, time and resources which improved this study.

\section{REFERENCES}

Bozhinskiy, A. N., M. S. Krass and V. V. Popovnin. 1986. Role of debris cover in the thermal physics of glaciers. 7. Glaciol., 32(111), 255-266.

Cordell, L., J. Phillips and R.H. Goodson. 1992. U.S. Geological Survey potential-field geophysical software. U.S. Geol. Surv. Open-File Rep. 92-18.

Corte, A. E. and L. E. Espizua. 1981. Inventario de glaciares de la cuenca del Rio Mendoza. Mendoza, Instituto Argentino de Nivología y Glaciología.

Crandell, D. R. 1980. Recent eruptive history of Mount Hood, Oregon, and potential hazards from future eruptions. U.S. Geol. Surv. Bull. 1492.

Driedger, C. L. and P. M. Kennard. 1986. Ice volumes on Cascade volcanoes: Mount Rainier, Mount Hood, Three Sisters, and Mount Shasta. U.S. Geol. Surv. Prof. Pap. 1365.

Lawrence, D. B. 1948. Mount Hood's latest eruption and glacier advances. Mazama, 30, 22-29.

Meier, M.F. 1984. Contribution of small glaciers to global sea level. Science, 226(4681), 1418-1421.

Nakawo, M. and G.J. Young. 1982. Estimate of glacier ablation under a debris layer from surface temperature and meteorological variables. 7. Glaciol., 28(98), 29 34.

Shreve, R. L. 1972. The movement of water in glaciers. $\mathcal{F}$. Glaciol., 11(62), 205-214.

Small, R.J. 1987. Englacial and supraglacial sediment: transport and deposition. In Gurnell, A. M. and M.J. Clark, eds. Glacio-fluvial sediment transfer; an alpine perspective. Chichester, etc., John Wiley and Sons, $111-145$.

The accuracy of references in the text and in this list is the responsibility of the authors, to whom queries should be addressed. 